POIMEN : Jurnal Pastoral Konseling

ISSN (Print) : :2723-5645

ISSN (Online) : 2723-5637

http://ejournal-iakn-manado.ac.id/index.php/poimen

Vol.1, No.2, pp. 1 - 84, Desember 2020

Diterima $\quad 25$ November 2020

Disetujui 30 Desember 2020

\title{
Analisis Kesulitan Belajar Mahasiswa Pada Mata Kuliah Bahasa Inggris
}

\author{
Analysis of Student Learning Difficulties in English Subject \\ Fienny M. Langi \\ Institut Agama Kristen Negeri Manado Email : fiennylangi@iakn-manado.ac.id
}

\begin{abstract}
ABSTRAK
Penelitian ini bermaksud untuk menganalisis kesulitan belajar mahasiswa pada mata kuliah Bahasa Inggris. Studi kasus ini dilakukan di IAKN Manado, khususnya pada 30 mahasiswa semester satu tahun ajaran 2019/2020 dari 3 program studi yang berbeda. Peneliti menggunakan pendekatan klasik dan individual untuk menggabungkan data, dan dianalisa dengan metode deskriptif kualitatif. Hasil penelitian menunjukkan bahwa kesulitan belajar mahasiswa terjadi karena adanya perasaan terpaksa dalam belajar, rendahnya penguasaan konsep belajar, tidak bisa mengingat pelajaran, dan tidak memiliki kesempatan untuk berlatih Bahasa Inggris. Mengacu pada temuan yang ada, disarankan agar tenaga pengajar dan Lembaga harus memfasilitasi dan memberikan motivasi yang tinggi untuk proses belajar Bahasa Inggris.
\end{abstract}

Kata Kunci : kesulitan belajar, mahasiswa, bahasa inggris

\section{ABSTRACT}

This study intends to analyze student learning difficulties in English language courses. This case study was conducted at IAKN Manado, specifically 30 students in the first semester of the 2019/2020 school year from 3 different study programs. Researchers use a classic and individual approach to combine data, and analyzed with qualitative descriptive methods. The results showed that students' learning difficulties occurred due to feelings of compulsion in learning, poor mastery of learning concepts, being unable to remember lessons, and not having the opportunity to practice English. Referring to the findings, it is recommended that the teacher and institutions should facilitate and provide high motivation for the learning process of English.

Key Words : learning difficulties, student, english 


\section{A. PENDAHULUAN}

Perguruan tinggi adalah suatu jenjang pendidikan tinggi yang memiliki pola pembelajaran yang berbeda, sehingga mereka yang mengikuti pendidikan di tingkat ini diberi tambahan kata'maha', sebagai pembeda dengan mereka yang belajar di tingkat yang lebih rendah. Negara merumuskan perguruan tinggi sebagai kelanjutan dari pendidikan menengah yang diselenggarakan untuk mempersiapkan peserta didik agar menjadi anggota masyarakat yang memiliki kemampuan akademis dan professional yang dapat menerapkan, mengembangkan, dan menciptkan ilmu pengetahuan, teknologi dan kesenian. ${ }^{1}$

IAKN Manado adalah salah satu perguruan tinggi yang memiliki peserta didik dengan prestasi belajar yang bervariasi. Prestasi belajar yang bervariasi ini menjadikan keaktifan peserta didik dalam proses belajar mengajar, menjadi berbeda. Belajar itu sendiri adalah suatu perubahan didalam kepribadian yang menyatakan diri sebagai suatu pola baru daripada reaksi yang berupa kecakapan, sikap, kebiasaan, kepandaian, atau suatu pengertian. ${ }^{2}$ Proses belajar yang dilakukan di IAKN Manado meliputi berbagai mata kuliah, sehingga perbedaan prestasi belajar di kelas menyebabkan terjadinya kesenjangan dalam proses pembelajaran, terutama dalam mata kuliah Bahasa Inggris.

Penguasaan Bahasa Inggris merupakan sarana untuk mendongkrak sumber daya manusia Indonesia. Persaingan global di segala bidang menuntut peningkatan kualitas sumber daya manusia (SDM). Dalam dunia pendidikan, khususnya di perguruan tinggi, output perguruan tinggi (PT) harus benar-benar berkualitas agar berdaya saing dan benilai tinggi. Salah satu upaya untuk mewujudkan hal tersebut adalah dengan meningkatkan kualitas pembelajaran BI. Penguasaan BI akan membuka wawasan mereka terhadap perkembangan ilmu pengetahuan dan teknologi, termasuk pendidikan yang saat ini dapat diakses dengan mudah dari berbagai sumber. Peningkatan mutu pembelajaran BI dapat tercapai jika diketahui latar belakang kesulitan belajarnya. Informasi tentang kesulitan belajar dapat digunakan sebagai dasar penentuan tujuan, metoda, strategi, dan materi

\footnotetext{
${ }^{1}$ UU no. 2 tahun 1989 , pasal 16 ayat 1

${ }^{2}$ Syaiful Bahri D, 2018 dalam Farida
} 
pembelajaran yang relevan dengan kebutuhan lulusan. Untuk itu, diperlukan kajian mengenai latar belakang kesulitan belajar dalam mata kuliah Bahasa Inggris..

\section{B. DESKRIPSI TEORETIK}

Kesulitan belajar atau dikenal juga dengan sebutan learning difficulty adalah salah satu gangguan proses psikologis yang mencakup pemahaman dan penggunaan bahasa ujaran atau tulisan. Gangguan tersebut dapat terwujud dalam bentuk kesulitan mendengarkan, berpikir, berbicara, membaca, menulis, mengeja, atau berhitung. Abdurrahman ${ }^{3}$ merumuskan kesulitan belajar sebagai suatu ketidakmampuan nyata pada orang - orang yang mempunyai intelegensi rata - rata hingga superior, namun memiliki cara belajar yang kurang baik dan tidak memuaskan. Kesulitan belajar tidak hanya menimpa mahasiswa berkemampuan rendah saja, tetapi juga dialami oleh siswa yang berkemampuan tinggi ataupun siswa dengan kemampuan normal.

Kesulitan belajar seseorang biasanya tampak jelas dari menurunnya kinerja akademik atau prestasi belajarnya. Hal - hal tersebut disebabkan oleh faktor faktor tertentu yang menghambat tercapainya kinerja akademik yang sesuai dengan harapan. Ahmadi mengemukakan faktor-faktor penyebab kesulitan belajar dapat digolongkan ke dalam 2 golongan yaitu faktor internal dan faktor eksternal. Faktor internal berupa hal-hal atau keadaan-keadaan yang muncul dari dalam diri siswa sendiri seperti faktor fisologi (yang bersifat jasmani) seperti sakit atau tidak fit, dan faktor psikiologis (yang bersifat rohani) seperti tingkat kecerdasan, sikap siswa, bakat siswa, minat siswa, motivasi siswa. ${ }^{4}$ Faktor Eksternal seperti hal-hal atau keadaan-keadaan yang datang dari luar diri siswa. Faktor eksternal ini meliputi faktor non sosial seperti keluarga, keadaan ekonomi, alat pelajaran, kondisi gedung, kurikulum, waktu sekolah dan disiplin kerja, orang tua dan faktor sosial seperti media massa, teman bergaul, lingkungan tetangga, aktivitas dalam masyarakat.

Pembelajaran (learning) adalah proses sadar yang melibatkan memori seseorang terkait dengan informasi yang sedang dipelajari, misalnya mengucapkan salam, menggunakan kaidah-kaidah bahasa, dan kosakata ${ }^{5}$. Pembelajaran bahasa

\footnotetext{
${ }^{3}$ Abdurrahman, 1999

${ }^{4}$ Ahmadi, 1991 dalam Farida

5 Tomlinson, 1998: 4
} 
dapat berupa pengetahuan tentang sistem bahasa (language usage) dan penggunaan bahasa (language use). Pembelajaran bahasa modern melibatkan lembaga, pengajar, pembelajar, dan pengajaran ${ }^{6}$ serta mengutamakan pengalaman belajar, penghargaan diri (self-esteem), keterlibatan emosional, keterhubungan pembelajaran dengan daya pikir, penggunaan bahasa secara komunikatif, dan materi pembelajaran yang mendorong kreativitas pembelajar.

Berdasarkan pengalaman dan fakta selama perkuliahan, masih ditemukan adanya kesalahan- kesalahan yang dilakukan mahasiswa dalam menyelesaikan soal-soal mata kuliah Bahasa Ingris yang berakibat pada rendahnya hasil belajar. Dari kesalahan yang dilakukan, dapat diteliti dan dikaji lebih lanjut mengenai sumber kesalahan mahasiswa dan upaya pemecahannya. Berdasarkan uraian tersebut, perlunya dilakukan penggalian informasi tentang faktor-faktor yang menyebabkan kesulitan mahasiswa dan mengetahui letak kesalahan yang dilakukan mahasiswa dalam menyelesaikan soal-soal Bahasa Inggris.

Penelitian ini diharapkan dapat melengkapi penelitian - penelitian sebelumnya dalam fokus kesulitan belajar. Ada beberapa penelitian dengan topik yang sama, seperti yang dilakukan oleh Hermayawati tentang Analisis Kesulitan Belajar Bahasa Inggris Mahasiswa yang menemukan bahwa adanya kesulitan belajar karena kurangnya motivasi dan fasilitas mahasiswa. Ada juga Dian Nugraheni dengan Analisis Kesulitan Belajar pada Mata Kuliah Mekanika yang menemukan bahwa letak kesulitan belajar ada pada kemampuan dasar mahasiswa yang masih kurang.

\section{METODOLOGI}

Jenis penelitian ini adalah suatu penelitian studi kasus yang melibatkan 30 mahasiwa IAKN Manado Program Studi PKAUD semester 1, Program Studi Sosiologi Agama semester 1, dan Program Studi Musik Gereja semester 1, dengan menggunakan teknik analisis data deskriptif kulaitatif yang menguraikan data bukan dengan angka, melainkan dalam bentuk narasi. Penelitian ini bertujuan mendeskripsikan secara rinci analisis kesulitan belajar mahasiswa, khususnya untuk mata kuliah Bahasa Inggris, dan dibatasi hanya kepada mahasiswa semester

\footnotetext{
${ }^{6}$ Richards, 2001b: 198
} 
satu tahun ajaran 2019 - 2020 di IAKN Manado. Proses pengumpulan data menggunakan instrument : (1) peneliti sebagai pengumpul data, (2) observasi proses belajar (3) open questionnaire (4) dokumen berupa hasil tes formatif, tes ujian tengah semester, dan tes ujian akhir semester, (5) wawancara mendalam dengan mahasiswa, khususnya yang bermasalah dalam proses pembelajaran Bahasa Inggris.

Data yang terkumpul dikategorikan sesuai dengan variable kajian, lalu peneliti menganalisis hasil kuesioner, wawancara, dan tes, kemudian divalidasi menggunakan teknik triangulasi teori, sumber data dan peer-debriefing (validasi melalui sumber yang belum pernah dikaji). Data kuesionernya berupa jawaban informant menyangkut motivasi belajar, intakes, peranan dosen dan mahasiswa dalam pembelajaran, sarana prasarana yang tersedia, materi pembelajaran, dan lingkungan belajar mereka. Semua data disortir dan dikategorikan menjadi: (1) Low-motivated with Low-achievement, (2) Well-motivated with Lowachievement, (3) Stabilized-progress with Stable-achievement, (4) Progressiveexperience with Significant-achievement yang dikodifikasi menjadi Evenly dan Significantly Progress. ${ }^{7}$

\section{HASIL DAN PEMBAHASAN}

Dalam penelitian ini, peneliti mengumpulkan informasi melalui tes maupun wawancara pada mahasiswa sebagai responden. Berdasarkan hasil jawaban, peneliti memperoleh data - data yang menunjukkan beberapa mahasiswa mengalami kesulitan belajar dengan faktor - faktor pendukungnya sendiri. Faktor - faktor yang menyebabkan kesulitan belajar mahasiswa dalam mata kuliah bahasa Inggris, terdiri dari :

A. Faktor Internal, berupa:

1. Aspek Kognitif

Subjek mengalami kesulitan belajar dalam ranah ini, dilihat dari kurangnya kemampuan ketrampilan menghafal dan kemampuan menguasai materi, serta kebiasaan belajar yang salah.

2. Aspek Afektif

\footnotetext{
${ }^{7}$ Hermayawati, 2010
} 
Subjek mengalami kesulitan belajar ditunjukkan dengan kurangnya minat terhadap tugas yang diberikan, kurang memusatkan perhatian, menghindari tangging jawab, malas belajar, dan sering tidak masuk kelas.

3. Aspek Psikomotorik

Gangguan psikomotorik yang menjadi faktor penyebab adalah kesulitan yang dialami subjek berupa terganggunya alat - alat ucap dan indra penglihatan serta pendengaran.

B. Faktor Eksternal, seperti:

1. Lingkungan Keluarga

Untuk lingkungan keluarga, yang menjadi faktor penyebab utama adalah kurangnya fasilitas belajar di rumah seperti meja belajar dan ruangan untuk belajar. Keadaan di rumah yang kurang mendukung responden untuk belajar, mengakibatkan terjadinya penurunan minat belajar mahasiswa.

2. Lingkungan Kampus

Dalam lingkungan kampus, faktor penyebab mahasiswa mengalami kesulitan belajar adalah hubungan antara dosen dan mahasiswa, cara mengajar dosen, serta tidak adanya fasilitas pendukung yang memadai seperti laboratorium bahasa yang bisa diakses mahasiswa saat kelas Bahasa Inggris. Mata kuliah Bahasa Inggris yang juga hanya diajarkan satu semester saja, dengan kapasitas 2 SKS, mengakibatkan tidak adanya minat belajar lebih lanjut bagi responden.

3. Lingkungan Masyarakat

Kondisi ingkungan masyarakat yang tidak menggunakan Bahasa Inggris, menjadi salah satu penyebab kesulitan belajar responden. Mahasiswa yang tidak terbiasa dengan Bahasa Inggris sebagai bahasa kedua, merasa malu dan takut apabila disuruh berbicara menggunakan bahasa Inggris di dalam kelas.

Faktor - faktor tersebut menyebabkan timbulnya kesulitan belajar pada mahasiswa, yang dalam penelitian ini diklasifikasikan menjadi 4 kategori.

1. Motivasi rendah dengan pencapaian rendah (Low-motivated with Low achievement category) 
Ada tiga responden yang termasuk dalam kategori ini. Mereka masuk dalam kategori ini dilihat dari jawaban kuesioner dan wawancara. Ada yang mengatakan tidak sungguh - sungguh belajar karena bosan, ada yang tidak mengerti dengan apa yang diucapkan dosen, dan ada yang selalu ditertawakan teman saat pelajaran speaking. Berdasarkan hasil penelitian, ditemukan bahwa tiga subjek ini sama sekali tidak menyukai Bahasa Inggris. Mereka bukan hanya tidak suka belajar, tetapi juga tidak ingin mencoba belajar Bahasa Inggris dengan cara apapun juga.

Responden dalam kategori ini tidak membutuhkan pengembangan secara spesifik, karena rendahnya kesadaran belajar akan menimbulkan kesulitan bahkan trauma apabila mereka tetap dipaksa untuk melakukan hal yang tidak mereka sukai secara spesifik. Salah satu faktor penyebab kesulitan belajar dalam kelompok ini adalah faktor kognitif berupa ketrampilan menghafal, penguasaan materi, dan kebiasaan belajar yang salah. Hal ini sesuai dengan teori Gestalt ${ }^{8}$ yang menyatakan bahwa proses belajar memerlukan satu kesatuan aspek seperti berpikir, mengingat, dan kesadaran diri. Apabila tidak adanya kesadaran dari diri sendiri untuk belajar dan mengembangkan diri, maka sebesar apapun stimulus yang diberikan tetap tidak akan berdampak bagi mereka.

2. Motivasi tinggi dengan pencapaian rendah (Well-motivated with Low achievement category)

Peneliti mengelompokkan 8 responden untuk masuk dalam kategori ini. Ada mahasiswa yang senang belajar bahasa Inggris karena menganggap penting untuk menghadapi era globalisasi. Ada juga yang menggemari Bahasa Inggris karena memiliki pengalaman menarik dengan guru Bahasa Inggris saat SMA. Beberapa mahasiswa termotivasi belajar bahasa Inggris karena ingin tampil dimuka umum dengan pronounciation yang baik, meskipun secara hasil dan pencapaian mereka belum terlalu baik. Beberapa diantara mereka merasa belum adanya peningkatan hasil belajar namun memiliki niat untuk meningkatkan hasil dan prestasi belajar. Berdasarkan survey tersebut, dapat disimpulkan bahwa responden memiliki niat dan

${ }^{8}$ Wooffolk, dalam Hermayanti 2010 
motivasi belajar yang tinggi, namun keterbatasan kemampuan awal yang kurang menyebabkan mereka memiliki hasil belajar yang rendah.

Kemampuan awal yang rendah itu disebabkan oleh faktor afektif dan lingkungan masyarakat yang tidak mendukung. Kedua faktor diatas membuat mereka sangat lamban dalam memberi respon terhadap stimulus dosen. Namun, hal ini akan bisa teratasi dengan memberikan pelajaran secara berulang - ulang terhadap mahasiswa dalam kelompok ini. Hanya saja, kendala yang dihadapi adalah keterbatasan waktu pembelajaran Bahasa Inggris di semester satu.

3. Motivasi stabil dengan pencapaian stabil (Stabilized-progress with Stableachievement Category)

Kategori Stabilized-progress with Stable-achievement meliputi 12 mahasiswa. Hampir seluruh ekspresi dalam kategori data ini mempunyai kesan dan motivasi yang baik tentang pembelajaran Bahasa Inggris, sejak mereka duduk di bangku sekolah menengah hingga menjadi mahasiswa. Berikut ini adalah cuplikan persepsi mereka berkaitan dengan pengalaman belajar Bahasa Inggris: (1) Ada mahasiswa yang sebenarnya sangat berminat belajar Bahasa Inggris apabila faktor pendukungnya benar-benar ada, yang artinya guru mampu memotivasi siswa. (2) Ada mahasiswa yang merasa dosen Bahasa Inggris kurang tegas dan keras sehingga mahasiswa kurang termotivasi belajar; (3) Ada mahasiswa yang berpendapat bahwa peningkatan minat belajar tergantung pada kemauan dan kemampuan masing-masing mahasiswa - jika punya kemampuan, pasti ada peningkatan; (4) Di perguruan tinggi mayoritas mahasiswa sudah lupa Bahasa Inggris. Untungnya menurut mereka, dosen Bahasa Inggris sangat baik karena ia mampu membimbing mereka dari awal dengan penuh kesabaran; (5) Ada mahasiswa yang mengusulkan agar frekuensi belajar Bahasa Inggris ditambah secara proporsional; (6) Ada mahasiswa yang merasa puas dengan metode pengajaran yang digunakan oleh guru di sekolah menengah karena selalu mendapat nilai paling rendah tujuh, meskipun tidak pernah kursus; (7) Ada mahasiswa yang menilai dosennya adalah sosok wanita karier yang patut ditiru karena kedisiplinan, keuletan dan kegigihannya dalam mengajar 
mahasiswa walaupun mahasiswa tersebut memiliki nilai Bahasa Inggris yang rendah.

Responden dalam kelompok ini memiliki pengalaman belajar yang baik sejak di Sekolah Menengah sehingga mudah bagi mereka untuk mengembangkan kompetensi, baik secara mandiri maupun lewat bimbingan dosen. Responden dari kelompok ini juga memiliki hasil belajar yang relative tinggi, dilihat dari hasil tes formatif, ujian tengah semester, dan ujian akhir semester.

4. Motivasi tinggi dengan pencapaian tinggi (Progressive-experience with Significant-achievement Category)

Kelompok ini memiliki persamaan persepsi tentang pengalaman belajar Bahasa Inggris, baik sejak di tingkat sekolah menengah, ataupun di tingkat perguruan tinggi. Ada 7 responden yang dikelompokkan dalam kategori ini. Mereka merasa senang dengan cara mengajar dosen Bahasa Inggris, menyadari pentingnya penggunaan bahasa Inggris, dan memiliki motivasi belajar yang tinggi, walaupun kurangnya sarana pendukung eksternal seperti laboratorium bahasa yang belum lengkap, alat dan materi pelajaran yang belum memadai, dan lain sebagainya.

Rata - rata mahasiswa mengatakan bahwa meskipun merasa kurang menguasai kosakata dan tenses, mereka mengalami peningkatan belajar di perguruan tinggi. Dalam angket juga disebutkan bahwa mereka merasa lebih termotivasi saat praktek Speaking, karena dosen bahasa Inggris selalu memberi semangat dan bukan menertawakan atau menghukum apabila terjadi kesalahan dalam penyebutan kosakata. Beberapa responden mengusulkan agar dosen mata kuliah Bahasa Inggris membawa mahasiswa untuk field trip ke tempat - tempat dengan potensi wisatawan mancanegara, untuk bisa praktik speaking langsung dengan native speaker.

Kesulitan belajar yang dialami oleh kelompok ini terjadi karena mereka harus menyesuaikan diri dengan lingkungan baru, dari lingkungan sekolah menengah ke lingkungan perguruan tinggi yang lebih dinamis. Hal - hal seperti itu menyebabkan mereka tidak fokus dan kadang melupakan detail pelajaran dasar yang didapatkan di Sekolah menengah. Unsur 'lupa' adalah 
sesuatu yang wajar menurut Klein, karena terjadinya penumpukkan memori baru yang saling mengintervensi dalam formasi syaraf otak, dan kegagalan dalam menghadirkan berbagai ekspresi kebahasaan yang sebelumnya pernah dipelajari selama bertahun - tahun. ${ }^{9}$

Hasil yang diperoleh diatas merupakan penjabaran dari data nilai yang ada, kemudian dipadukan dengan hasil wawancara terhadap subjek penelitian dalam pembahasan penelitian ini. Tidak menutup kemungkinan masih ada faktor lain yang menyebabkan mahasiswa mengalami kesulitan dalam menyelesaikan soal - soal Bahasa Inggris, yang tidak terungkap dalam penelitian ini.

\section{PENUTUP}

Berdasarkan hasil penelitian dan pembahasan dapat disimpulkan bahwa kesulitan belajar yang dialami oleh mahasiswa semester 1 IAKN Manado ada pada kemampuan Speaking, Listening dan Grammar. Kesulitan yang dialami mahasiswa terletak pada kesalahan dalam penyebutan, kesalahan penulisan, dan kesalahan dalam mengerjakan soal latihan untuk tata bahasa Inggris.

Beberapa sebab rendahnya hasil belajar Bahasa Inggris adalah sebagai berikut: (1) Mahasiswa kurang menguasai materi Bahasa Inggris pada tingkat Pendidikan sebelumnya, yaitu di Sekolah Menengah (2) Mahasiswa kurang menguasai dan memahami konsep-konsep Bahasa Inggris secara mantap; (3) Mahasiswa kurang mampu belajar mandiri, masih menggunakan metode hafalan; (4) Mahasiswa kurang cermat dan teliti dalam mengerjakan soal. Banyaknya kesalahan yang dilakukan mahasiswa dalam mengerjakan soal bisa menjadi petunjuk sejauh mana penguasaan mereka terhadap materi-materi yang ada. Hasil penelitian ini kemudian akan dijadikan bahan pengembangan untuk strategi pembelajaran, agar untuk selanjutnya mahasiswa dapat lebih memiliki kemampuan belajar dan berpikir yang baik.

\section{Ucapan Terima Kasih}

Penelitian yang dilakuan ini masih memiliki banyak kekurangan, namun dengan adanya dukungan dari beberapa pihak penelitian ini dapat berjalan dengan lancar tanpa ada hambatan apapun dan dapat terselesaikan secara maksimal.

\footnotetext{
${ }^{9}$ Klein, 1996
} 
Oleh karena itu, peneliti mengucapkan terima kasih kepada mahasiswa IAKN Manado Program Studi Pastoral Konseling semester 1, Program Studi Sosiologi Agama semester 1, dan Program Studi Musik Gereja semester 1, sebagai responden dan subjek penelitian untuk tulisan ini.

\section{DAFTAR PUSTAKA}

Anni, C., T. 2004. Psikologi belajar. Semarang: Unnes Press.

Budiyono. 2003. Metodologi penelitian pendidikan. Surakarta: Sebelas Maret University

Press.

Farida Ariami, Slamet Mulyana, dan Asem. 2009. Pelajaran Mendengarkan. Jakarta : Pusat Pengembangan dan Pemberdayaan Pendidikan dan Tenaga Kependidikan Bahasa.

Partowisastro, K. (1986). Diagnosa dan pemecahan kesulitan belajar 1. Jakarta: Erlangga

Richards, Jack C. 2001. Curriculum and Materials Development for English Teaching. Cambridge: Cambridge University Press.

Suryani, Y.E. 2010. Kesulitan belajar. Magistra, No. 73 Th. XXII.

Undang-Undang No. 20 Tahun 2003 tentang Sistem Pendidikan Nasional (UUSPN).

Tomlinson, Brian. 1998. Materials Development in Language Teaching. Cambridge: Cambridge University Press.

Tomlinson, Brian. \& Masuhara, Hitomi. 2004. Developing Language Course Materials. Singapore: SEAMEO Regional Language Centre.

Woolfolk, Anita., et al. (1984). Educational Psychology for Teachers. New Jersey: Prentice-Hall Inc. 